\title{
OBITUARIES
}

\section{Dr. Allen Benjamin Dobkin}

Dr. A.B. Dobin died at Syracuse, New York, on December 12, 1978. Ben, as he was generally known, was born on July 25, 1923 in Toronto and graduated in Medicine from the University of Toronto in 1949. He served a rotating internship at Mount Sinai Hospital in Cleveland, Ohio and after an assistant residency in Surgery proceeded to the University of Minnesota wher'e he served as Fellow in Anesthesiology, followed in 1953-54 by a research fellowship at McGill. He joined the Department of Anaesthesia at the University of Saskatchewan as an Assistant Professor in 1955 when the department was in its formative years and spent the next five years there in tireless activity, helping to build up the department and engaging in a formidable array of research projects. He left Saskatoon to assume the chairmanship of the Department of Anesthesiology at New York State University Upstate Medical Center in Syracuse, a position which he held until a few years ago, when he decided to devote more time to research. Poor health forced him to curtail these activities, but he remained active in many endeavours related to anaesthesia until his untimely death.

Ben Dobkin was a Diplomate of the American Board of Anesthesiology, a Fellow of the American College of Anesthesiology, held the Specialist Certificate in Anaesthesia of the Royal College of Physicians and Surgeons of Canada, and was a member of many anaesthesia societies. He was a prolific writer and a familiar figure at anaesthesia meetings around the world. His contributions to anaesthesia have been many and important, and he was a frequent contributor to this journal. Although he became an American citizen upon taking up residence in the United States, he never lost his attachment to his native land and frequently returned here to visit. There have been very few Annual Meetings of the Canadian Anaesthetists' Society which he did not attend. Ben was a devoted family man. If he had any hobby other than anaesthesia and research, it was travelling. He will be sorely missed by his numerous friends in many countries, and our sincere sympathy goes out to his two sons and his wife Edythe.

\section{Dr. Keith Gordon Grant}

We have just recently been informed of the death of Dr. Keith Gordon Grant, of Winnipeg. on April 29, 1978, at the age of 91 years.

Dr. Grant was born in Bristol, England, on June 16, 1886. Emigrating to Canada, he qualified in Medicine at McGill University. He became interested in Anuesthesia as a Medical Officer during World War I. He joined the staff of the Winnipeg General Hospital in 1922, and was one of the few full-time professional anaesthetists in western Canada at that time. On retiring from practise in 1963 he was elected to Honorary Life Membership in The Canadian Anaesthetists' Society.

Dr. Grant is survived by his wife Marjory, son Robert and three grandchildren.

\section{Dr. Alexander Ralph Wilkins}

Dr. A.R. Wilkins died at Toronto on January 1 , 1979 , in his 85 th year. Born at Arthur, Ontario, on August 9th, 1894, he was educated in the Public School and High School in Arthur and at the University of Toronto. Graduating in Pharmacy (Phm.B.) in 1915, he served overseas with the Canadian Army Medical Corps as a Dispenser during World War 1. On his return to Canada he enrolled in the Faculty of Medicine, University of Toronto, and graduated in 1924.

After two years of interneship at Toronto General Hospital, Dr. Wilkins was appointed to the staff of the Department of Anaesthesia at Toronto General Hospital and University of Toronto in 1925 . He retired from that appointment in 1962 , but continued until 1975 with the general practice of medicine in Toronto which he had conducted throughout his career. For many years before and during World War Il he was active in the Royal Canadian Army Medical Corps and was Medical Officer altached to the Queen's Own Rifles of Canada.

Dr. Wilkins is survived by his wife Eden (nee Walker), son Peter, daughter Barbara and six grandchildren. 